\title{
Spreading Knowledge in Medical Informatics: the Contribution of the Hospital Italiano de Buenos Aires
}

\author{
F. Gonzalez Bernaldo de Quiros, D. Luna, P. Otero, A. Baum, D. Borbolla \\ Department of Health Informatics, Hospital Italiano de Buenos Aires, Buenos Aires, Argentina
}

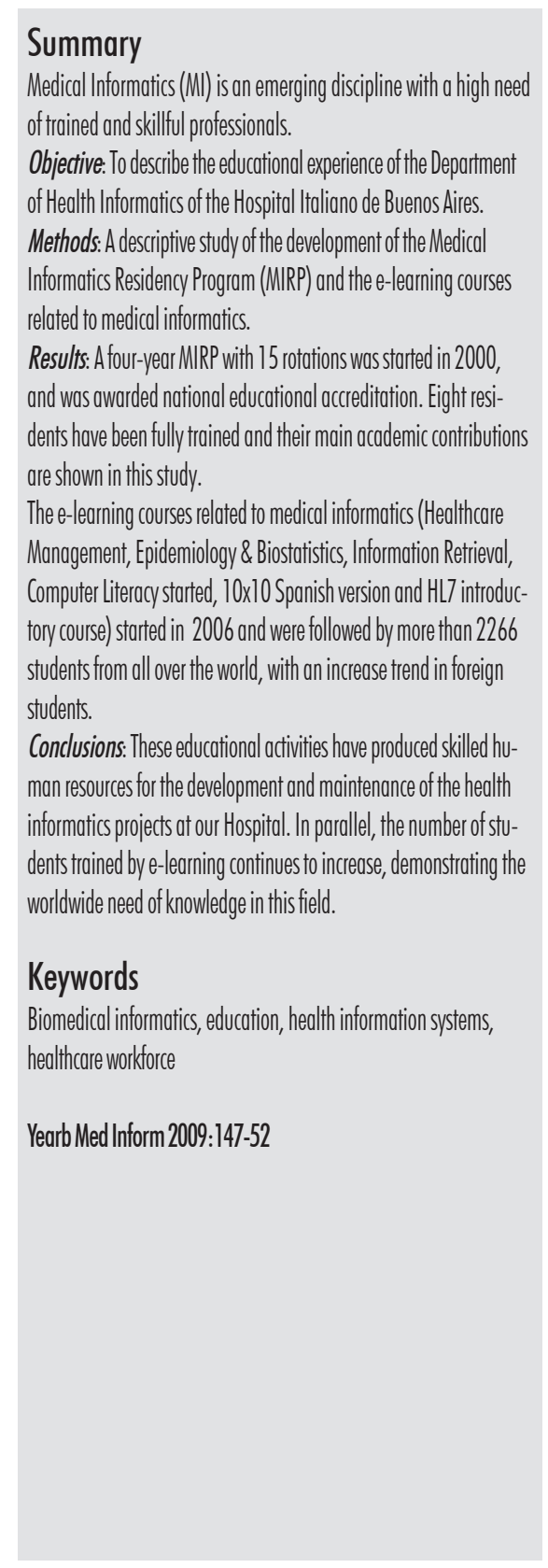

\section{Introduction}

Medical Informatics (MI) is an emerging discipline that has been growing for the last 20 years [1]. It has been defined as the field concerned with the management and use of information in health and biomedicine [2]. It is generally acknowledged that MI is a discipline that requires trained and skilled professionals $[2,3]$ since it is not only related with computers and technology, but also with how information is obtained and used in its context [4].

One well-known initiative that addresses the need for training in MI is the $10 \times 10$ program launched in 2005 by the American Medical Informatics Association (AMIA) and the Department of Health Informatics \& Clinical Epidemiology of Oregon Health \& Science University (OHSU). Having a similar aim in mind, the Hospital Italiano de Buenos Aires (HIBA), a non-profit healthcare academic center founded in 1853, started a graduate and postgraduate education program in 2001, with the goal of achieving great impact in the Latin American region (22).

The educational offer of HIBA includes $30+$ medical residency-training programs, 34 fellowship programs, a School of Medicine, and a School of Nursing. The MI residency is one of the most recent medical residency programs, having been created in 2000 . Since 2006, HIBA also uses an e-learning platform aiming to teach professionals who are interested in MI and other medical issues, all over the world.
The objective of the present study is to describe the incremental contribution of the Hospital Italiano de Buenos Aires to the educational need in this field.

\section{Methods}

Study design: A description of the residency program and virtual courses at HIBA between 2006 and 2008 .

\section{Setting}

HIBA has a network of 2 hospitals amounting to 750 beds (200 for intensive care) 500 home-care patients under care, and 23 clinics. Its insurance plan covers approximately 150,000 people and it also coordinates insurance for another 1,500,000 people who are covered by affiliated insurers. Each year over 36,000 inpatients (pediatric and adult) are admitted to our hospitals, which are located in the city of Buenos Aires and suburban area. More than 2,400,000 outpatient visits from patients from all over the country and Latin America are received in the HIBA.

In 1998 HIBA decided to implement a Healthcare Information System (HIS) called "ITALICA". It is an in-house project that currently handles all the information related to healthcare both clinical and administrative from its capture to its analysis. As part of the project, the Department of Health Informatics was created in 2001 involving 120 people including clinicians, IT pro 
fessionals and technicians. (Figure 1). The e-learning management system is Moodle (Modular-Object-OrientedDynamic-Learning-Module-Environment), a free, open-source package designed to help educators create effective online learning communities [5].

\section{Results}

\section{A - Residency Program in Medical Informatics}

The four-year Medical Informatics Residency program was created in 2000 in order to train human resources in this field. Currently it is the only program of its kind in Argentina and was recently approved by the National Commission for Universities Evaluation - CONEAU as a postgraduate medical specialty degree course.

The main objective of the program is to train physicians to be liaisons between the healthcare and the information technology in the life cycle of health information systems. A multidisciplinary team is engaged in the program including IT specialists, clinicians (physicians and nurses), statisticians, epidemiologists, healthcare managers and anthropologists or social science experts.

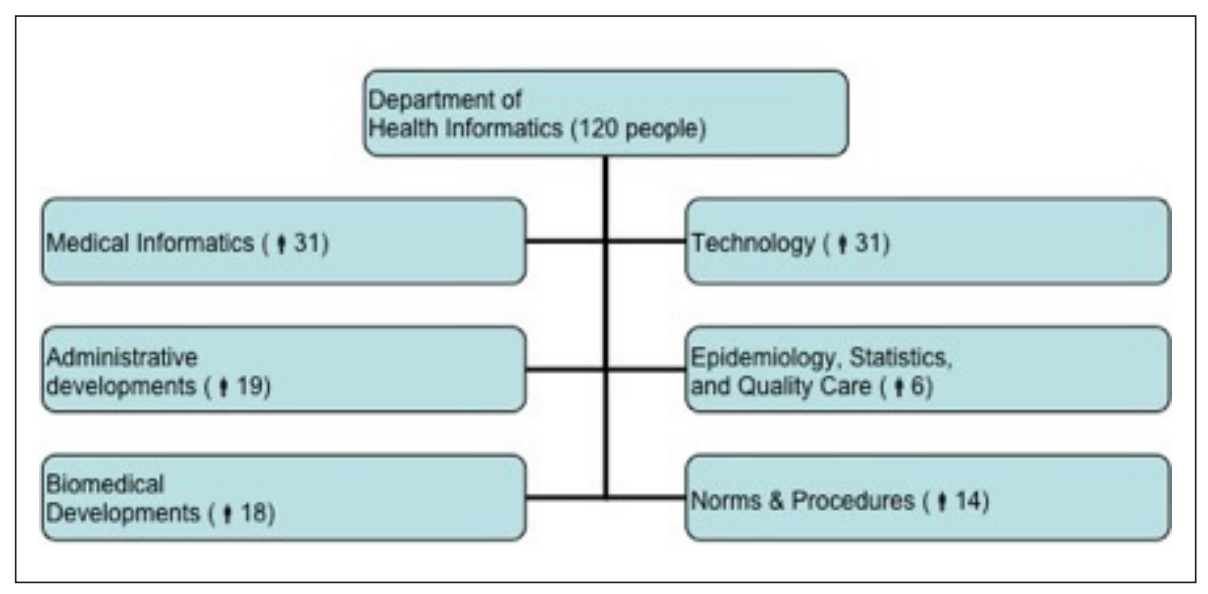

Fig. 1 Organization of the Department of Health Informatics at Hospital Italiano de Buenos Aires

The program offers 15 rotations with both theoretical and practical aspects that allow residents to participate in the analysis, design, development, implementation and evaluation of the ITALICA project. The objectives and duration of the rotations of the residency as well as their main academic contributions are shown in Table 1.

Since 2001 eight residents have been trained (mean age of 26 years, 25\% female).

Residents are involved in the development and maintenance of the hospital's information system (ITALICA), which handles non-clinical information from local master files and clinical information that includes diagnosis, medical tests, drugs and medical devices, is stored in a clinical terminology server that facilitates semantic interoperability [6]. The residents work consists of a local interface terminology (thesaurus) mapped to a reference vocabulary, SNOMED CT [7]. The thesaurus is a list of terms created from almost 2 million free text inputs extracted from the clinical data repository. The local interface terminology allows users to record clinical data choosing options

Table 1 Objectives, duration in months and main academic contributions of the MI residency rotations at the HIBA

\begin{tabular}{|c|c|c|}
\hline Rotation (duration in month) & $\begin{array}{c}\text { Main } \\
\text { objectives/skills }\end{array}$ & Peer-reviewed publications \\
\hline $\begin{array}{l}\text { Introduction to Biomedical } \\
\text { Informatics (3) }\end{array}$ & - 10x10 program & $\begin{array}{l}\text { Otero P, Hersh W, Luna D, Lopez Osornio A, González Bernaldo de Quirós F. Translating implementation and evaluation of a } \\
\text { medical informatics distance learning course for Latin America. 12th World Congress on Health Informatics. Brisbane, Australia. } \\
20-24 \text { August 2007. (CD) P421 }\end{array}$ \\
\hline Health Information Systems (2) & $\begin{array}{l}\text { - EMR design and } \\
\text { implementation }\end{array}$ & $\begin{array}{l}\text { Osornio AL, Marti SG, Gambarte L, Staccia G, Schpillberg M, Soriano E, Otero P, Luna D, Gonzalez Bernaldo de Quiros F. Creation } \\
\text { of a web-based icpc encoder and a secondary codification variability. Developing tools from a free text variability analysis of } \\
\text { diagnostic descriptions records. Medinfo. 2004; 2004(CD): 1789. } \\
\text { Borbolla D, Giunta D, Figar S, Soriano M, Dawidowski A, González Bernaldo de Quiros F. Effectiveness of a chronic disease } \\
\text { surveillance systems for blood pressure monitoring. Stud Health Technol Inform. 2007; V. 129, p 223-7. PMID: 17911711 } \\
\text { Montenegro S, Rubinstein F, Kopitowski K, Michelangelo H, Lopez Osornio A, Luna D, Soriano E, González Bernaldo de Quirós F. } \\
\text { Development and implementation of Physician Profiling Tool. 12th World Congress on Health Informatics. Brisbane, Australia. } \\
20-24 \text { August 2007. (CD) P478 }\end{array}$ \\
\hline Interoperability and security (3) & $\begin{array}{l}\text { - Master file (development } \\
\text { and maintainance) } \\
\text { - HL7 }\end{array}$ & \\
\hline
\end{tabular}




\begin{tabular}{|c|c|c|}
\hline $\begin{array}{l}\text { Management of biomedical } \\
\text { knowledge (3) }\end{array}$ & $\begin{array}{l}\text { - Terminology Server } \\
\text { (development and } \\
\text { maintainance) } \\
\text { - Information Retrieval }\end{array}$ & $\begin{array}{l}\text { Reynoso, G; March, A; Berra, C; Strobietto, R; Barani, M; lubattii, M; Chiaradio; M P; Serebrisky, D; Kahn, A; Vaccarezza, O; } \\
\text { Leguiza, J; Ceitlin, M; Luna, D; González Bernaldo de Quirós, F; Otegui, M I; Puga, M C; Vallejos, M. Development of the } \\
\text { Spanish Versión of the Systematized Nomenclature of Medicine: Methodology and Main Issues. Publicado en los Proceedings } \\
\text { del Simposio Anual de la American Medical Informatics Association. Noviembre del 2000. PMID: } 11079973 \\
\text { Otero P, Pedernera F, Montenegro S, Borbolla D, Garcia Marti S, Luna D, Gonzalez Bernaldo de Quiros F. Evolution of medical } \\
\text { informatics in bibliographic databases Stud Health Technol Inform. 2004;107 (Pt I):301-5. PMID: } 15360823 \\
\text { Gambarte ML, Lopez Osornio A, Martinez M, Reynoso G, Luna D, González Bernaldo de Quiros F. A practical approach to advanced } \\
\text { terminology services in health information systems Stud Health Technol Inform - 2007, v.129, p.621-5 PMID: } 17911791 \\
\text { Lopez Osornio A, Luna D, Gambarte ML, Gomez A, Reynoso G, González Bernaldo de Quiros F. Creation of a Local Interface } \\
\text { Terminology to SNOMED CT. Stud Health Technol Inform - 2007, v.129, p.765-9 PMID: 17911820 } \\
\text { Campbell J, Lopez Osornio A, González Bernaldo de Quirós F, Luna D, Reynoso G. Semantic interoperability and Snomed (T: A Case } \\
\text { Study in dinical problem lists. 12th World Congress on Health Informatics. Brisbane, Australia. 20-24 August 2007. (D) P387 }\end{array}$ \\
\hline $\begin{array}{l}\text { Change management in medical } \\
\text { informatics (4) }\end{array}$ & $\begin{array}{l}\text { - Information needs } \\
\text { - Psicosocial and } \\
\text { Organizational aspects } \\
\text { - Usability concepts }\end{array}$ & $\begin{array}{l}\text { Luna D, Osornio AL, Marti SG, Lopez G,Ciffarelli G, Otero P, Gonzalez Bernaldo de Quiros F, Soriano E, Durante E. Patients and } \\
\text { Physicians have different opinions about the use of a Computer Patient Record System in ambulatory setting. Medinfo. 2004; } \\
\text { 2004(CD):1731. } \\
\text { Dawidowski A, Toselli L, Luna D, Oberti P, Soto M, González Bernaldo de Quirós F. [Changes in physicians' attitudes to computerized } \\
\text { ambulatory medical record systems: a longitudinal qualitative study] Gac Sanit - 2007, v.21, p.384-9 PMID: } 17916302 \\
\text { Baum A, Mauro A, Luna D, Gonzźlez Bernaldo de Quirós F. Evaluating designs against users requirements in Latin America: an } \\
\text { experience of human-centred methods, techniques and tools on a low budget. 12th World Congress on Health Informatics. } \\
\text { Brisbane, Australia. 20-24 August 2007. (CD) P416 }\end{array}$ \\
\hline Applied clinical informatics (4) & $\begin{array}{l}\text { - Clinical Decision Support } \\
\text { Systems }\end{array}$ & $\begin{array}{l}\text { Luna D, Otero V, Canosa D, Montenegro S, Otero P, de Quirós FG. Analysis and redesign of a knowledge database for a drug- } \\
\text { drug interactions alert system. Studies in health technology and informatics - 2007, v.129, p.5 PMID: } 17911843\end{array}$ \\
\hline $\begin{array}{l}\text { Health Informatics } \\
\text { Subespecidilities (3) }\end{array}$ & $\begin{array}{l}\text { - Telemedicine } \\
\text { - Nursing Informatics }\end{array}$ & $\begin{array}{l}\text { Pedernera F, Luna D, Plazzoftta F, Gassino F, Martinez M, González Bernaldo de Quirós F. Remote follow-up of liver transplant } \\
\text { patients: a telemedicina implementation Project in Latin America. 12th World Congress on Health Informatics. Brisbane, } \\
\text { Australia. 20-24 August 2007. (CD) P432 }\end{array}$ \\
\hline $\begin{array}{l}\text { Multimedia in health } \\
\text { informatics (2) }\end{array}$ & - RIS/ PACS & $\begin{array}{l}\text { Sosa G, Navas H, Cancio A, Plazzotta F, Otero P, Luna D, González Bernaldo de Quirós F. Integration of specialist and ancillary } \\
\text { services system into a HIS: Development and implementation of a generic report system. 12th World Congress on Health } \\
\text { Informatics. Brisbane, Australia. 20-24 August 2007. (CD) P251 } \\
\text { Gonzźlez Bernaldo de Quirós F, Plazzotta F, Gomez A, Luna D. Interoperability and Security: Design and development of a } \\
\text { Clinical Document Repository Digitally Signed using CDA Standard. 12th World Congress on Health Informatics. Brisbane, } \\
\text { Australia. 20-24 August 2007. (CD) P390 }\end{array}$ \\
\hline $\begin{array}{l}\text { Evaluation in Medical } \\
\text { Informatics (2) }\end{array}$ & & $\begin{array}{l}\text { Navas H, Lopez Osornio A, Baum A, Gomez A, Luna D, González Bernaldo de Quiros F. Creation and evaluation of a terminology } \\
\text { server for the interactive coding of discharge summaries. Stud Health Technol Inform - 2007, v. 129, p.650-4 PMID: } 17911797 \\
\text { Mauro A, Baum A, Galarza C, Otero P, Luna D, González Bernaldo de Quirós F. Value Added: needs, motivations, hopes and } \\
\text { fears of Argentine patients about the development of their personal health records. 12th World Congress on Health Informatics. } \\
\text { Brisbane, Australia. 20-24 August 2007. (CD) P007 } \\
\text { Dawidowski A, Baum A, Mauro A, Schachner V, de los Rios E, Luna D, Gonźlez Bernaldo de Quirós F. An ethnographic focus for } \\
\text { the study of information needs in the emergency center of the Hospital Italiano de Buenos Aires. 12th World Congress on Health } \\
\text { Informatics. Brisbane, Australia. 20-24 August 2007. (CD) P334 }\end{array}$ \\
\hline Project Management (2) & & $\begin{array}{l}\text { Baum A, Figar S, Serverino J, Assale D, Schachner B, Otero P, Luna D, Gonzalez Bernaldo de Quiros F. Assessing the Impact of } \\
\text { Change in the Organization of a Technical Support System for a Health Information Systems. Stud Health Technol Inform. } \\
\text { 2004;107(Pt 2):1367-70. PMID: 15361038 }\end{array}$ \\
\hline Mapping process (2) & & $\begin{array}{l}\text { Plazzofta F, Benitez S, Fabini D, Schachner B, Mogni V, Luna D, González Bernaldo de Quirós F. Shortage of beds: A local } \\
\text { solution for a global concern. A traffic light system. 12th World Congress on Health Informatics. Brisbane, Australia. 20-24 } \\
\text { August 2007. (CD) P262 }\end{array}$ \\
\hline Computer Literacy (6) & & $\begin{array}{l}\text { Galarza, Carlos R; Cuffaro, Paula E; Luna, Daniel; Gómez, Adrián; Reynoso, Ariel; Langlois, Esteban; Mussi, Carlos; Marchetti, } \\
\text { Marcelo; González Bernaldo de Quirós, Fernán. - Calidad de comunicación para una mejor salud. Oportunidad y desafío de la } \\
\text { World Wide Web / Quality of communication for a better health. Opportunity and challenge of the World Wide Web. Nexo rev. } \\
\text { Hosp. Ital. B.Aires; 23(2):8-13, jun. 2003.ilus. ID } 391885\end{array}$ \\
\hline Health Management (24) & & $\begin{array}{l}\text { Figar S, Waisman G, González Bernaldo de Quirós F, Galarza C, Marchetti M, Rodríguez Loria G, Camera L, Seinhart D, Camera } \\
\text { M. Narrowing the Gap in Hipertensión: Effectiveness of a Complex Anthypertensive Program in the Elderly. Disease } \\
\text { Management, Volume 7, Number 3, 2004. PMID: } 15669583\end{array}$ \\
\hline Epidemiology & $\begin{array}{l}\text { - Software development } \\
\text { for the surveillance of } \\
\text { chronic diseases }\end{array}$ & $\begin{array}{l}\text { Software for Follow-Up and Control of a Patient Population With Chronic Diseases. Technol Health Care. } 2004 \text { December } \\
\text { 2004;12(5):369. }\end{array}$ \\
\hline
\end{tabular}


from a list of familiar terms but storing information coded with SNOMED CT [8]. The system also provides users with the equivalence of a given local term in standard classifications such as ICD-9CM, ICD-10 or ICPC2, and includes a model for dynamic subset definitions, which are a set of rules that allow the definition of a subset in terms of their relationships with SNOMED CT concepts [9-11].

Residents also work on the development and implementation of the EHR, which is patient-centered and problemoriented and is currently working in outpatient, inpatient, emergency care and home care settings with different modalities of implementation. A Picture Archive and Communication Systems (PACS) and a Signal Archive and Communication System (SACS) were recently implemented and provide full interoperability between images and the EHR, thus enabling the images and signals to be seen directly from the EHR application [12].

A Chronic Disease Management System (CDMS) that uses clinical information from the EHR has also been implemented [13, 14]. It was awarded the "Best International Disease Management Program" prize, at the 5th Annual DMAA (Disease Management Association of America) Conference in 2003, Chicago, USA.

A Personal Health Record has been created that helps patients participate more actively and interact with different areas of the HIS ]. A project for the implementation of a clinical decision support system called "Sebastian", developed at Duke University, is also being tested [16].

\section{B - E-learning Courses Related to Medical Informatics}

The first e-learning course was launched in 2006 focused on computer literacy and information retrieval. Figure 2 shows the temporal linear trend in the annual number of students. Most of the students were from Argentina and from other Spanish-speaking countries. A world map with the total number of students that attended the e-learning courses is shown in Figure 3.

\section{Description of the e-Courses}

Introduction to Biomedical Informatics (in collaboration with AMIA's $10 \times 10$ training program)

The initial work consisted of the adaptation of the different modules offered by OHSU to Latin American needs. The course provides general knowledge on biomedical informatics focusing on clinical care and public health by covering topics such as: elec- tronic health records, terminology and standards, healthcare quality and patient safety. The main goal is to provide students with tools to develop or take part in a team that provides solutions to healthcare problems with the help of IT. By the end of the course, the students are expected to be able to implement health informatics projects in their institutions.

The course was launched in March 2006 and, after 4 revisions, contains 11 current modules designed to be delivered in twelve one-week units, requiring about ten hours of work per week, through the Virtual Campus of HIBA.

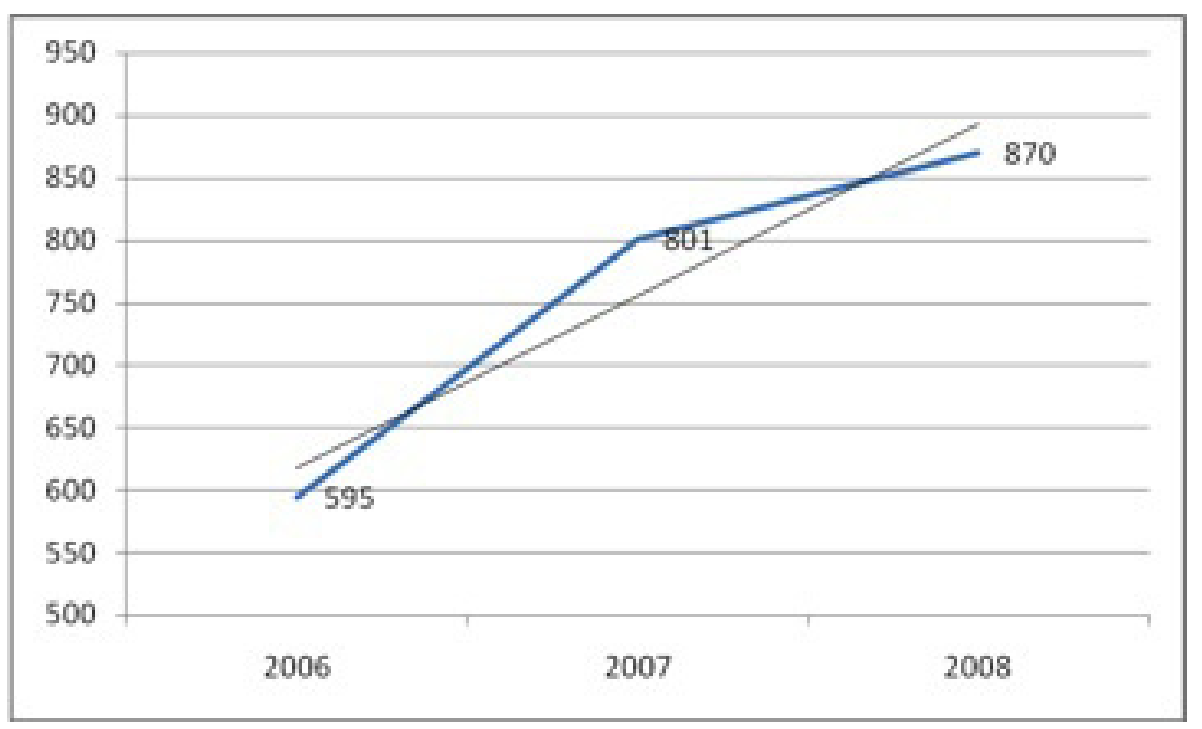

Fig. 2 Annual number of students of e-learning courses delivered by the Hospital Italiano de Buenos Aires

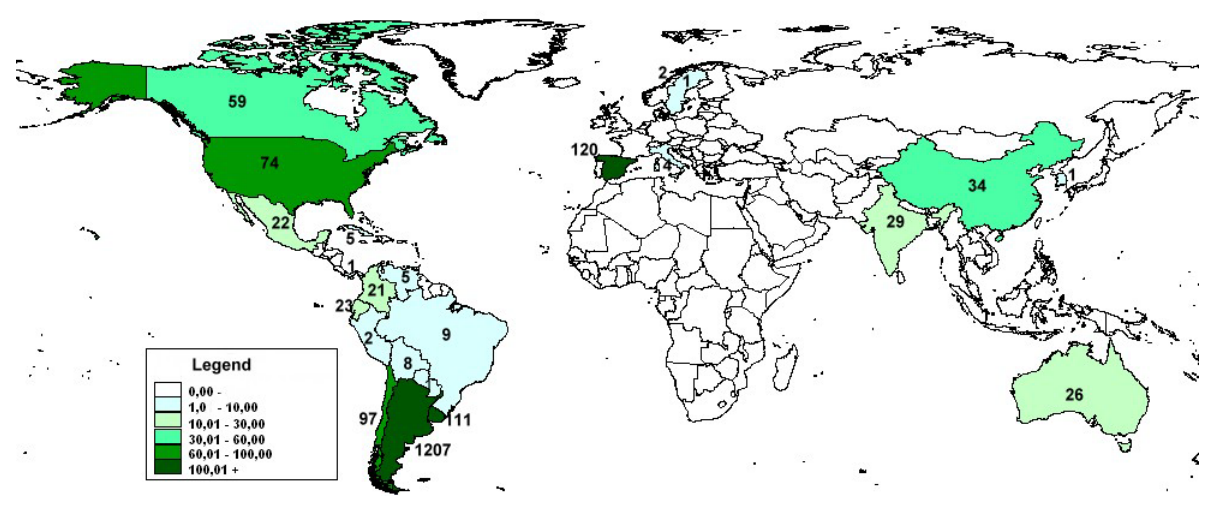

Fig. 3 Number of students by country of e-learning courses on health informatics delivered by the Hospital Italiano de Buenos Aires 
The teaching modalities used for the course include lectures, threaded discussion boards, recommended readings, and self-assessment. The final evaluation of the student consists of a written test where students have to answer three multi-part questions. All students who pass the evaluation obtain a certificate of completion issued by AMIA and the School of Medicine of HIBA.

At the end of the course, the students are surveyed about the course characteristics, the interaction with their teachers, the e- learning modality and the main features of the course using a Likert scale (1 worst to 5 best). The overall average score obtained was 4.3/5.

The course is supported by an 850 page handbook made from the content of all the modules, and is used as bibliographic material in Spanish, in order to help people to learn in their own language, since most of the learning material, books and journals available from the specialty are mostly available in English.

\section{Computer Literacy Course}

This course aims at training healthcare professionals in the use of office automation applications, with a focus on Microsoft's Windows operating system, on the structure and functioning of the Internet, and especially on learning how to use a word processor, a spreadsheet, a database management system, and a multimedia presentation authoring tool. We believe that there is a lack of this type of training, especially in healthcare professionals. We used the competencies catalogue proposed by the International Computer Driving License (ICDL).

\section{Information Retrieval Course}

This online course teaches the most important subject-specific scholarly information sources and basic skills for systematic information retrieval. Students are trained to understand how information is stored and organized in bibliographic databases, to acknowledge different information needs, to turn them into an answerable question, to learn how to use bibliographic databases such as MEDLINE, to complement with the use of other web resources, and to create personal bibliographic databases using a software tool for publishing and managing them.

\section{Introduction to HL7 Course}

The Department of Health Informatics at HIBA has collaborated with HL7 Argentina and HL7 International for the development of this course, which aims to introduce the key concepts of electronic messaging interoperability in health care. The course was initially developed in Spanish and later was translated into and adapted for the English language. Students are introduced to the key concepts in electronic messaging standards and communication focusing on the implementation of the HL7 messaging system, to understand and apply the Reference Information Model (RIM) in instances of data exchange and to apply a reference model for the exchange of clinical document. The course lasts 10 weeks and uses the Virtual Campus of HL7 Argentina; the students have weekly assignments with "hands-on" exercises on real interoperability problems.

\section{Health Care Management Course}

This 2-year course aims at improving the management capacity of professionals who will be CEO or CIO in healthcare institutions in Argentina by providing an introduction to healthcare management. The program contains the following modules: Management of healthcare systems, Healthcare information systems and introduction to medical informatics, Epidemiology applied to healthcare systems, Healthcare economics, Healthcare quality and circuits of continuous improvement and Management of Chronic diseases.

\section{Epidemiology and Biostatistics Course} This course for healthcare professionals teaches the basic concepts of epidemiology, the different study designs and the basics of descriptive and inferential statistics.

\section{Discussion}

The recommendations given by the International Medical Informatics Association on education in health and medical informatics are oriented to fulfill the training needs for the acquisition of knowledge and skills in information processing and information technology applied to healthcare. They also establish the importance to train human resources in this discipline, so that they can organize, coordinate and develop health informatics projects in healthcare facilities. These recommendations address the different topics or modules that need to be taught according to the level of education or type of work related to the field. Other authors have stated that well-trained health informatics workforce should know not only about healthcare but also about IT, business and management, communication and interpersonal skills. They should know as well how to cope with organizational change and project management [17-19].

We believe that Medical Informatics implies the integration of the following areas of knowledge: healthcare, computer science, healthcare information systems, management and quality indicators and epidemiology, biostatistics and decision making theory. Other areas include change management, project management, electronic health records, information retrieval, knowledge-based databases for clinical terminology and standards. The program aims to train human resources, that already have formal training in healthcare (mainly physicians), in the concepts and practice of computer science, to provide adequate knowledge of how healthcare systems work, healthcare management and also to acknowledge the importance of the adequate utilization of healthcare statistics for analysis.

Trainees actively participate in the development and implementation of an electronic health record so that they can also evaluate the impact these implementations have on healthcare in general.

The creation of the curriculum of the Medical Informatics residency program 
at Hospital Italiano was based on these recommendations; it was focused on the health informatics specialist level with a curriculum leading to a qualification as specialist in health informatics. We believe that the combination of training provided by both training courses and the possibility of hands-on training is particularly useful. The possibility of applying academic knowledge in real situations with difficult scenarios together with the interaction with end-users in the use of health information systems is an important learning experience.

The increase in the number of students when comparing from 2006 to 2008 signals a growing interest in the development of health informatics.

\section{Conclusion}

Our 7-year experience of training residents in health informatics both in theory and practice has enabled us to obtain skilled human resources, which now play an important role in the development and maintenance of health informatics projects at our hospital. The growing number of students trained by e-learning keeps increasing, showing a worldwide need of knowledge dissemination in this field, which our institution is contributing to.

\section{Acknowledgments}

We would like to thank Dr. William Hersh for his continuous support to our academic activities and Dr. Alvaro Margolis and Dr. Sergio Koenig for their assistance in the delivery of the AMIA 10x10 course in Uruguay and Chile. We thank Silvana Figar and Mercedes Soriano for their invaluable help in the development of the manuscript

\section{References}

1. Otero P, Pedernera F, Montenegro S, Borbolla D, Garcia Marti S, Luna D, et al. Evolution of medical informatics in bibliographic databases. Stud Health Technol Inform 2004;107(Pt 1):301-5.

2. Hersh W. Medical informatics education: an alternative pathway for training informationists. J Med Libr Assoc 2002 Jan;90(1):76-9.

3. Hersh W. Who are the informaticians? What we know and should know. J Am Med Inform Assoc 2006 Mar-Apr;13(2):166-70.

4. Hersh W. Health care information technology: progress and barriers. JAMA 2004 Nov 10; 292(18):2273-4.

5. Moodle - A Free, Open Source Course Management System for Online Learning. [Last visited: [03/25/2009]; Available from: http://moodle.org/.

6. Reynoso GA, March AD, Berra CM, Strobietto RP, Barani M, Iubatti M, et al. Development of the Spanish version of the Systematized Nomenclature of Medicine: methodology and main issues. Proc AMIA Symp 2000:694-8.

7. Osornio AL, Luna D, Gambarte ML, Gomez A, Reynoso G, de Quiros FG. Creation of a local interface terminology to SNOMED CT. Stud Health Technol Inform 2007;129(Pt 1):765-9.

8. Navas H, Lopez Osornio A, Baum A, Gomez A, Luna D, de Quiros FG. Creation and evaluation of a terminology server for the interactive coding of discharge summaries. Stud Health Technol Inform 2007;129:650-4.

9. Navas H, Lopez Osornio A, Elias Leguizamon G, Orrego N, Wassermann S, Luna D, et al., editors. Implementación de reglas para el control de modelado con SNOMED CT. INFOLAC 2008 - 3er Congreso Latinoamericano de Informática Médica; 2008; Buenos Aires, Argentina.

10. Luna D, Bernaldo de Quiros FG, Garfi L, Soriano E, O'Flaherty M. Reliability of secondary central coding of medical problems in primary care by non medical coders, using the International Classification of Primary Care (ICPC). Medinfo 2001;10(Pt 2):300.

11. Gambarte ML, Osornio AL, Martinez M, Reynoso G, Luna D, de Quiros FG. A practical approach to advanced terminology services in health information systems. Stud Health Technol Inform 2007;129(Pt 1):621-5.

12. Plazzotta F, Kaminker D, Campos F, Cancio A, Luna D, Seehaus A, et al., editors. Imágenes más allá del PACS: el Proyecto Historia Clínica Multimedia. INFOLAC 2008 - 3er Congreso Latinoamericano de Informática Médica; 2008;
Buenos Aires, Argentina.

13. Borbolla D, Giunta D, Figar S, Soriano M, Dawidowski A, de Quiros FG. Effectiveness of a chronic disease surveillance systems for blood pressure monitoring. Stud Health Technol Inform 2007;129:223-7.

14. Gonzalez Bernaldo de Quiros F, Dawidowski A, Baum A, Soriano M, Bravo M, Figar S, et al. Medical Program Administrator: a Study and Functional Analysis ff Software for Follow-Up and Control of a Patient Population With Chronic Diseases. Technol Health Care 2004 December 2004;12(5):369.

15. Mauro A, Baum A, Galarza C, Otero P, Luna D, editors. Value Added: Needs, Motivations, Hopes and Fears of Argentine Patients About the Development of their Personal Health Records. Medinfo; 2007; Brisbane: IOS Press.

16. Borbolla D, Otero C, Lobach DL, Kawamoto K, Gomez Saldaño AM, Lopez G, et al., editors. Evaluación de la Sensibilidad y Especificidad de un Sistema de Ayuda a la Toma de Decisiones con modelo de servicio. INFOLAC 2008 - 3er Congreso Latinoamericano de Informática Médica; 2008; Buenos Aires, Argentina.

17. Hoffmann S, Ash J. A survey of academic and industry professionals regarding the preferred skillset of graduates of medical informatics programs. Stud Health Technol Inform 2001;84(Pt 2):1028-32.

18. Monegain B. Healthcare IT: is it a breed apart? September 2004 [cited 2009 Last visited: [03/25/ 2009]; Available from: http://www.healthcareitnews. com/story.cms?id= 1522 .

19. Sable JH, Hales JW, Bopp KD. Medical informatics in healthcare organizations: a survey of healthcare information managers. Proc AMIA Symp 2000:744-8.

Correspondence to:

Fernan Gonzalez Bernaldo de Quiros

Department of Health Informatics

Hospital Italiano de Buenos Aires

Gascon 450

1181 Buenos Aires

Argentina

Tel/Fox: +54 1149815219

E-mail: fernan.quiros@hospitalitaliano.org.or 